\title{
Analysis of Circular Development and Investment Possibilities (Transport, Energy and Building) Related to International Sports Event Planning
}

\author{
Bálint Horváth ${ }^{1}$, Csaba Fogarassy ${ }^{2}$ \\ ${ }^{1}$ Climate Change Economics Research Centre, Szent István \\ University, Gödöllö, Páter Károly street 1. \\ horvath@carbonmanagement.hu \\ ${ }^{2}$ Climate Change Economics Research Centre, Szent István \\ University, Gödöllö, Páter Károly street 1. \\ fogarassy.csaba@gtk.szie.hu
}

\begin{abstract}
This study investigates the possibilities of various development areas (transport, energy, building) to make the cost-efficient realisation of high-profile investments, and organising and holding international sports events possible. Using a case study, the paper introduces development routes based on the evaluation of environmental and economic perspectives. The current research introduces the investment characteristics based on the development of the Hungarian building, energy and transport sectors for the 2017-2030 period. The main criterion is the integration of 'circular economy'. For sectors which operate with high material and energy consumption, the consideration of circular economy principles may prove to be important for sustainable development. Through planning highvolume sports and worldwide events, the usual development strategy for traffic systems focuses on public transport and rentable vehicles (f. e. electric scooter, or bicycle) which can decrease $\mathrm{CO}_{2}$ emissions via modern technological solutions. Regarding the buildings, sports arenas and related facilities, besides the existing low-carbon solutions, the functions of buildings must be expanded and their usage prolonged. The management of waste left after the life cycle is expended has to be pre-planned. These are the options for making the sector's GHG emissions decrease apart from circular tenders, which can be further combined with SMART energetic solutions.
\end{abstract}

Keywords: strategic development, buildings, energy production, transport, international sports event, Budapest

\section{INTRODUCTION}

The topic of this research is the identification of main attributes in major development routes of the most notable economic sectors related to organising Hungarian sports events. This is a requirement of making the negative external effects of development programmes disappear for important state investments. Recently, Hungary's name popped up as a possible host for multiple international sports events, of which the current analysis deals with the planning possibilities of the 2024 Budapest Olympics. Though the initiative to organise the event was cancelled, the case study nature of the research may help decision-makers and experts in planning other international sports events. 
Apart from analysing the economic aspects, environmental effects and sustainability also garnered increasing attention in recent decades regarding international sports events [1].

Among these, the Olympics were high-profile events, carrying a demonstration function due to their popularity [2]. The idea to keep the environment sustainable has been a criterion for the Olympic Committees since the 1970's.

Having the actual Olympics overdo the previous one in these terms has been an unwitten rule [3]. From this perspective, the most notable herald of a new age was the 2008 Olympics in Peking, when the realisation of sustainability was elevated to a whole new level [4]. Regardless, the cessation of Hungary's planning process, and the social resistance against the Budapest 2024 Olympics both had their reasons. Worldwide events like the Olympics always include the question of how much the environmental and social effects can be controlled, and how economic sustainability and splurging can be avoided.

The realisation of earlier event's project came with mandatory investments which put a lot of stress on national budgets for years to come. Not to mention that a significant part of the constructed infrastructure remained unused capacity after the Olympic Games concluded. This is no coincidence, as there are few countries in the world to generate social interest with national sports events which can measure up to that of the Olympic Games [5]. Therefore, in recent years, applying for the right to host the Olympic Games attracted less and less interest, and few governments were willing to take on the challenge of executing such projects. This also spurred the Olympic Committee to introduce changes which can help potential host countries. Such a change was how the earlier centralisation was discarded, stating that the Olympic Games must be organised in a single city. By now, what was a demerit for smaller countries like Hungary, became a merit overnight. The option to conclude the Games in a de-centralised manner became possible, which does not need the building of a robust infrastructure focused on a central location or city. Furthermore, it presented a valuable chance to ease the capitalcentric characteristic of Hungary by preparing for the games, which meant that the bigger rural cities could also aim at notable development funds.

The circular planning practice - based on material- and energy efficiency principles - is not only economically sound, but offers a huge advantage from the perspective of the environment. By discarding the option to construct needless infrastructures and planning 'smart buildings', the volume of environmental load can be significantly decreased. This means less pollutants are released into the atmosphere, and less waste is produced. However, beyond initial advantages, the disadvantages must be considered as well [6]. The problem is: what level of environmental pollution will result from transporting visitors from venue to venue, or other similar longdistance logistics tasks' execution. De-centralised organising does solve a lot of problems, but new ones surface again and again. These can affect long-term, up to region-level development programmes. Therefore, one of the main questions of this research is: what timeframe is needed to manage the development questions, which come up related to international sports events. The goal of this analysis is to determine main development areas within the most significant strategic sectors (building, energy, transport), and to identify development programmes within these aspects for the pre-planning phase of the Olympic Games (2017-2024), and after the games concluded (2024-2030). The study employs benchmarking method to compare different scenarios dealing with the tendencies of various sectors. This is necessary for the identification of positive and negative effects within the sectors, which can be further used to evaluate the options belonging to different development decisions. The present research offer decisionmakers solutions for universal practice. The results can help organising international sports events regardless of the scrapped Olympic Games. The next chapter introduces the methodology and indicator system in more detail. 


\section{METHOD AND MATERIALS}

Environmental protection initiatives and the complexity of the sector in question made induces the use of benchmarking method as the basis of this research. Benchmarking is a levelcomparison methodology which employs a specifically tailored indicator system to compare the state of a sector in time and space [7]. The mechanism evaluates the future state, based on a condition system tailored for the present state. The reason for choosing this methodology is that benchmarking itself is a malleable analysis method, which can be specifically suited to the analysis goals [8]. The research is based on the conclusions of earlier international sports events to serve as the criteria for choosing main planning sectors. These are built environment, energy and transport sectors, which were assessed using the cornerstones of the European Union's climate policy regulation. Therefore, the research aspects were:

- level of energy efficiency,

- share of renewable energy in the sector,

- decrease aspects of $\mathrm{CO}_{2}$ emission.

\subsection{Main points of evaluation}

Using the indicators, the "results" can be evaluated compared to the originally set goals. The base state indicators are the parameter characteristics of the 2024 period, which help to determine the target value of the indicators for the 2030 period. Based on the gathered information, the method indicates if the prognosis value for 2030 goes over or under the target value. The results will clearly show what kind of additional measures must be taken in the sector in order to reach the target values for the indicators.

\subsection{Analysis method of various indicators}

Within the various indicator groups, determining the characteristics of indicators happens by describing the reason for choosing the indicator itself, determining the base value or category for it, and describing the performance indicator (using expert evaluation). The method of evaluating performance is mainly made up from setting the operation boundaries of the indicator, which can be a percentage value, a precise limit value, or an evaluation category. The advantage of the method is that piling up externalities can be analysed for a single system in a way that multiple measurement units and categories are used in the analysis. This method makes it possible to include data sets in the analysis which are incomplete, or to efficiently compare fundamentally different attributes to each other.

The benchmarking analyses will show the total amount of externalities for each sector, and the ratio of positive and negative externality content in these sectors. The analyses were conducted for the timeframes of 2017-2024 (planning phase), and the 2024-2030 (phase after conclusion), and dealt with the sectors' renewable energy usage, energy efficiency, and $\mathrm{CO}_{2}$ emission decrease aspects. There are selected technological, environmental and economic indicators for all aspects, two for each indicator respectively. The description of the benchmarking indicator systems related to the built environment, energy and transport sectors can be found in Appendix 1's Tables 1-9. 


\section{RESULTS}

\subsection{Building sector}

In summary, there is a high amount of positive externalities piling up in the sector during the preparation, execution and post-execution phases of the international sports events. During these periods, the system already shows the effects of energy efficiency investments underway. A significant improvement can be seen for the 2024-2030 period from the perspective of all three aspects. Such a combination of positive externalities usually means that the sector has a lot of unused potential, or one of its sub-sectors. It mostly means social welfare losses due to unexploited capacity in the long-term. Figure 1 shows the total amount of externalities, and more specifically, the relation between positive externalities of various aspects and time intervals using a radar diagram. Based on the analysis, one of the most notable weaknesses of the sector is the high amount of buildings which are beyond their lifecycle. Furthermore, it's a significant issue that the analysis background is not acceptably up-to-date, the statistical data at hand is full of holes. The benchmark assessing the efficiency of investments clearly indicated that the costs invested in the sector will produce a return by indirect future sparing measures. It can only be realised from long-term (10-20 years) returns even in the best cases [9].

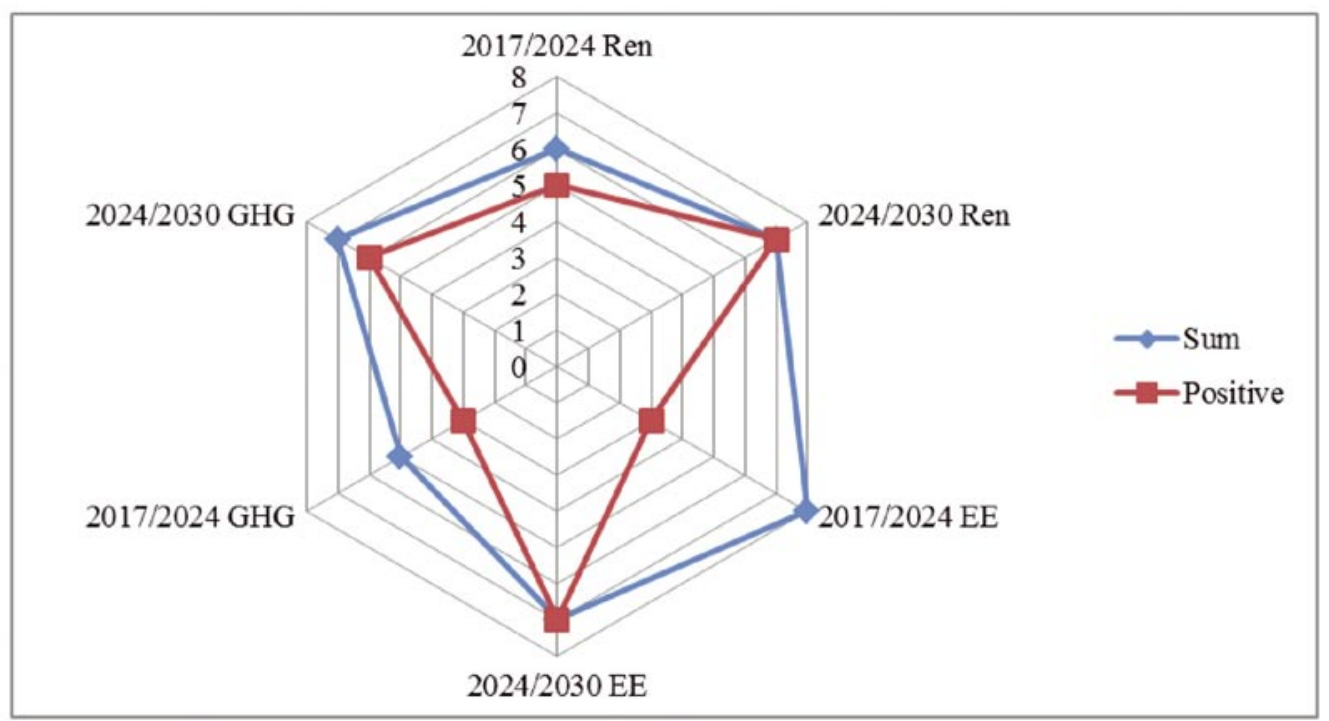

Figure 1. Externality content of the building sector

Abbreviations: Ren - Renewable energy; EE - Energy efficiency; GHG - Greenhouse Gases

In case of this sector, not only Hungary, but also the international community sees the most notable strength due to its cost-efficient GHG emission decrease potential, by which it can reach results of fundamental importance even in the short-term [10]. For Hungary, a further advantage can be the ambition the society shows as far as buildings are concerned. The government accepted multiple regulation initiatives which are still debated by other nations. One such case is that of 'zero energy' buildings, where they stated that after 2020, Hungary will only allow projects for the construction of such buildings [11, 12]. 
Another positive fact about the sector is that continuous technological developments and innovations make it possible to create systems more efficient and environment-friendly [13].

Furthermore, the social need for modern technological solutions is also strong in this sector. The civilian population mainly prefers their living environment to abide by the highest expectations. According to the calculations made for the Olympic Games, the level of environmental load related to operating infrastructures may reach up to $20-35 \%$ of the overall GHG emission [9]. It makes it indispensable to precisely plan the short- and longterm management of conditions related to maintaining buildings. In order to prepare these processes, green acquisition or its further evolved form must be used in order to realise tender programmes aiding circular system usage. The basics of designing a circular tender system can be eased by using the Building Research Establishment's Environmental Assessment Method (BREEAM).

\subsection{Energy Sector}

Being a strategic sector means that any kind of intervention has to be made only after a sufficient level of preparations. The current energy policy of the country significantly influences the sector's state. These condition systems cause the high difficulty of development in the sector, and that the decision-making processes of preparing developments lag behind. Furthermore, another risk factor is the international energy market's state, and the energy production attributes of third world countries. These aspects all influence the domestic production and consumption tendencies, the availability of the end product. The balance between supply and demand on the market is very sensitive to begin with [14]. The sector traditionally produces significant GHG emissions, which has several solutions for pushing back the emission rate.

An international tendency is introducing the CCS projects for technological solutions which have a high level of fossilised energy resource usage. In Hungary, this share is not significant, and a tendency to decrease is forecasted for the 2020 scenarios. In said scenarios, this kind of resource will make up a mere $5 \%$ of the energy mix, whereas the scenarios for 2030 calculate with a prognosis of nearly $0 \%$ [15]. The structure of this sector's externality content can be seen on Figure 2.

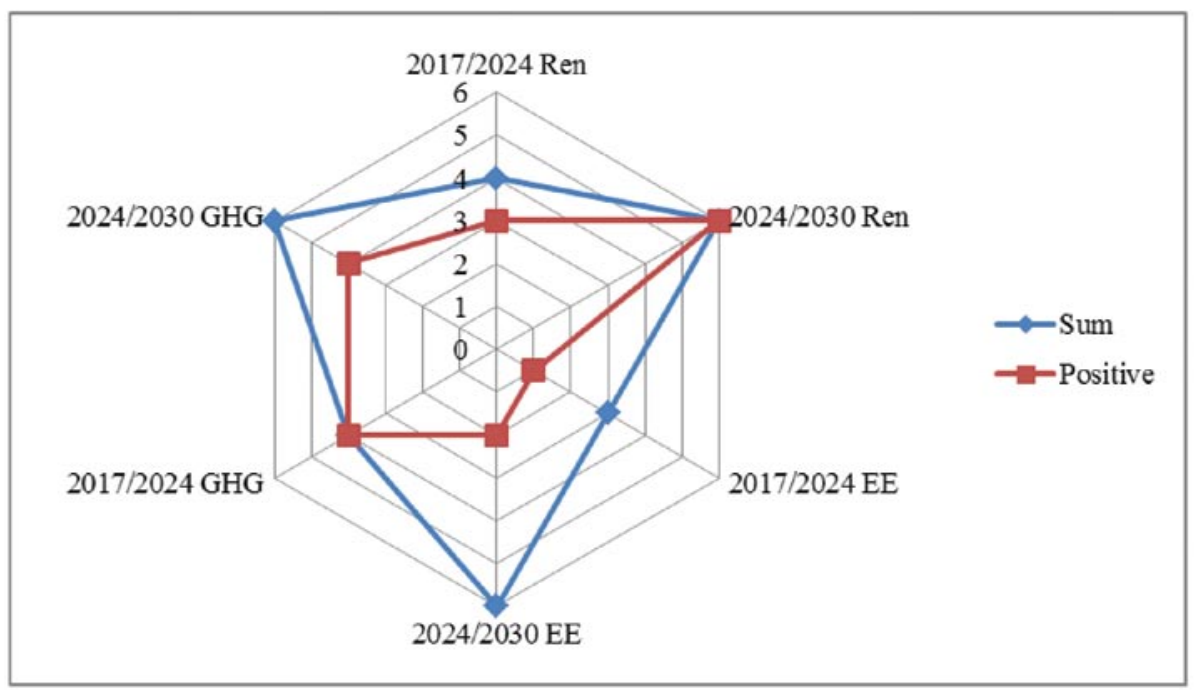

Figure 2. Externality content of the energy sector

Abbreviations: Ren - Renewable energy; EE - Energy efficiency; GHG - Greenhouse Gases 
Despite the European Union's priority target of increasing the share of renewable energy within the energy mix, this tendency cannot be accepted in Hungary for the examined time intervals. However, the results of the benchmarking analysis show that there is a major potential in this development route. For this period, the increase of nuclear energy's share is forecasted [16].

This means a clean energy source, its energy efficiency parameters are exceptional, but the negative environmental effects and the social opposition - and disadvantageous international feedback - may cause its development to run into problems. However, in the short-term it can influence the cost efficiency indicators negatively [17]. The mass of externalities seen on Figure 2 - which mainly gets outlined via macro-economic relations - shows mismatched development routes in the energy sector's high-profile investments, or the planning and realisation of gigantic sports events. Due to the renewable energy developments - which took up the tendency of getting delayed recently - the prognosis is that there is a strong renewable development potential both in the short- and long-term. It will unfold its true possibilities later by either the actualisation or the scrapping of Hungary's nuclear programme (PAKS-II). In case of sports investments, the most cost-efficient solution in short-term is to introduce energy management systems and self-sufficient energy supply systems. A good example is the RESCOOP system planned for the Olympic Village [18]. It would cover the energy requirement of not only most of the Olympic Village, but - due to its public ownership - it supports the energy consumption of the energy supply system's living environment after the sports event concluded.

\subsection{Transport sector}

One of the most notable attributes of the Hungarian transport sector - which is the one that rises above those of other EU member states' attributes the most - is the cost-efficient energy and material consumption decrease potential within it [19]. The renewable share and the decrease of $\mathrm{CO}_{2}$ emissions both have a low potential in the evaluated period. Perhaps only energy efficiency shows some improvements. According to the benchmarking analysis, although the notable increase in energy efficiency cannot be seen before 2024, it predicts a more significant improvement by 2030 in this field. Initiatives aiming at increasing energy efficiency in Hungary most likely were not successful due to the renewable energy resources and other low-carbon initiatives gaining ground rapidly. Instead, they were assisted by the development of traditional technological solutions [20]. From the perspective of developing and planning sports events, it might be advantageous to make technical requirements for traditional vehicles progressively stricter. From 2021, the area will experience a serious increase in regulation strictness by the EU [21]. The structure of externalities within the transport sector can be seen on Figure 3.

Based on the analysis, the Hungarian vehicle park will remain dependent on fossilised energy resources (diesel, gasoline) even by 2030. Significant decrease in dependence can only be reached by either introducing renewable energy resources or increasing the share of electric cars. The results of the benchmarking analysis show that in the analysed period, the share of public road traffic will increase by $4-5 \%$. Since it reduces the share of public transport, it means that more pollutants will be released.

In this period, forecasts state that the numbers of the car park will increase. It may be more energy efficient due to the ratio of newer models, but the total energy requirement and pollutant emission will increase. 


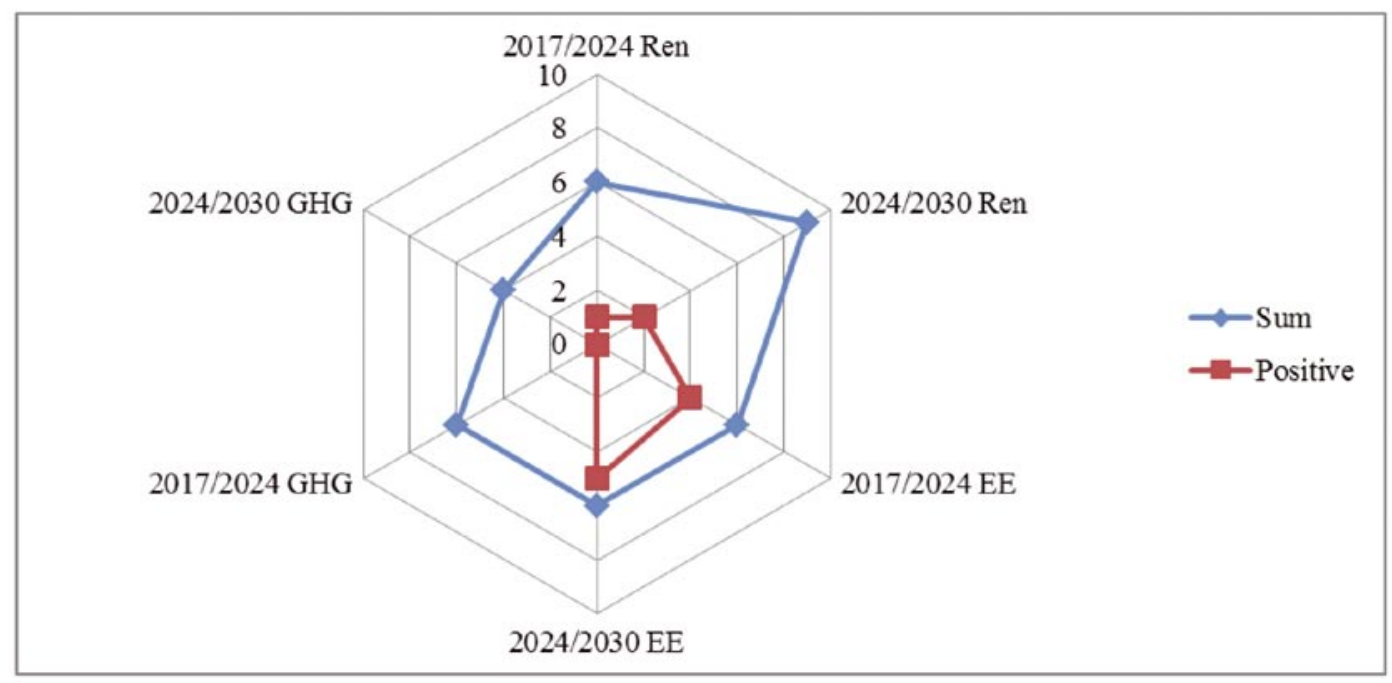

Figure 3. Externality content of the transport sector

Abbreviations: Ren - Renewable energy; EE - Energy efficiency; GHG - Greenhouse Gases

An increase in public demand for kilometres travelled can be observed, which will enhance both the distance made by vehicles, and through them, the emission rates. This tendency does not seem to decrease even in the analysed period. It is advised to design public awareness programmes for sports events which guide the demand resulting from this process towards a different result. It means not travelling by public roads, but promoting circular solutions and their planning as a matter of transition towards a sharing economy (sharing tools, f. e. cars, bicycles). The benchmarking analysis highlighted that the increase in energy efficiency does not show a significant leap by 2024 . Therefore, it is suggested to determine strategic goals during the logistical planning of sports events. They must offer solutions to the periodic, but progressively solidifying increase in transport needs by not only modernising the currently available vehicle park, but also introducing new and cost-efficient innovative methods. Prior analyses show that introducing the electric kickboards and planning their fleet usage may even decrease the traffic in Budapest's main business hours by up to $10-30 \%$.

\section{DISCUSSION}

Figure 5 shows the summary of the total externality content, which illustrates the number of externalities within the various sectors in the form of spheres. The size of the spheres indicates the amount of positive externalities within the various sector's total externality content - the bigger the sphere is, the more positive externalities it represents. The smaller it is, the higher the sector's negative externality content is. The time interval can be seen on the horizontal axis, which also lists the analysed aspects. The vertical axis shows the amount of externalities related to the time interval axis. The state of externalities identified by the analysis can show different conclusions for the various sectors.

Regarding the share of renewable sources for the 2017-2024 period, the highest amount of externalities - most of which are positive externalities - can be seen in the building sector. This means that during the planning processes, there is a significant opportunity for implementing new and innovative solutions into the system. 


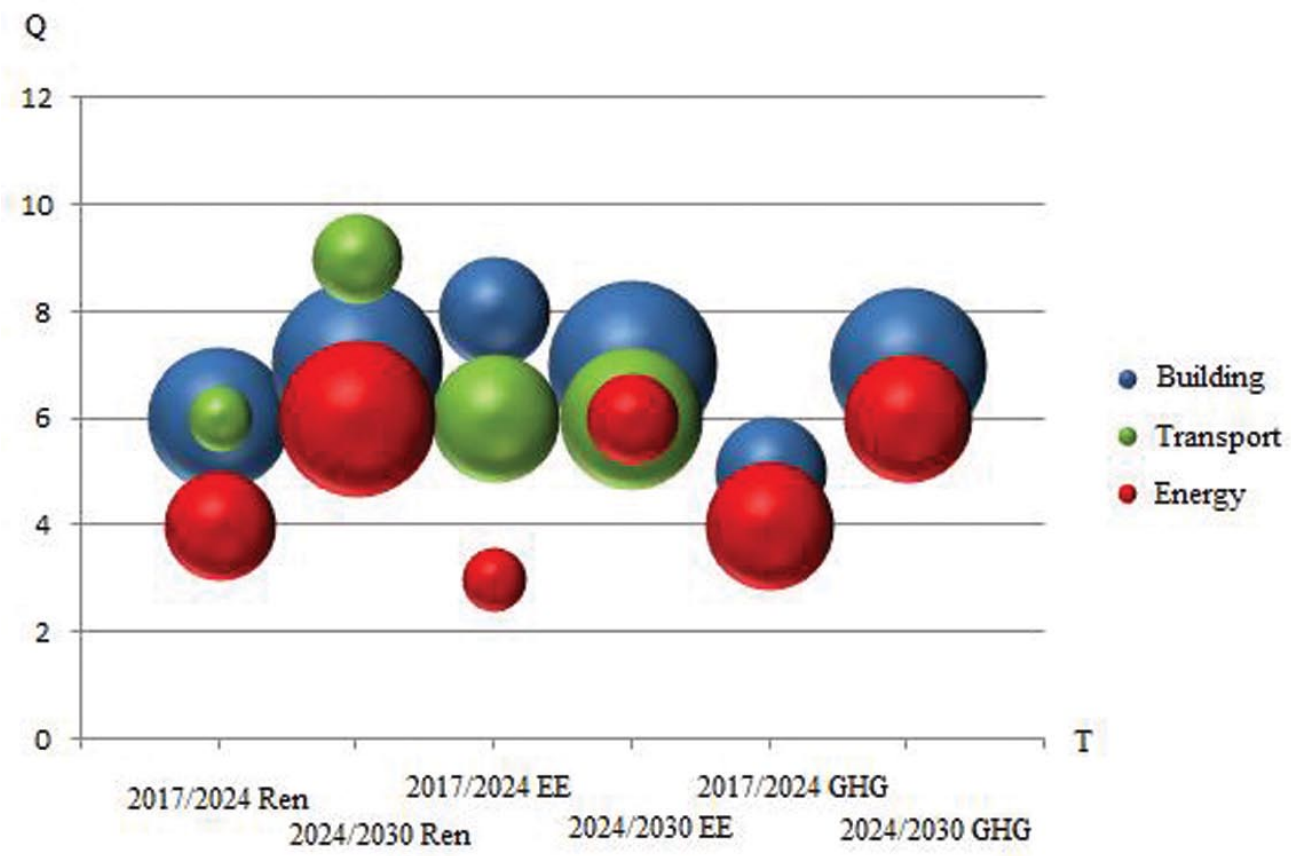

Figure 5. Total externality

Abbreviations: Ren - Renewable energy; EE - Energy efficiency; GHG - Greenhouse Gases

In this period, the negative externalities are the most numerous within the transport sector, among the various sectors included in the research. Moving on to the 2024-2030 period, the transport sector's development may show a significant improvement from the environmental perspective, but there is a notable potential in the energy sector too. By 2030, the most important progress may be foreseen for the energy sector, due to the introduction of renewable energy resources. The same tendency can be seen for buildings, as the results of preferring low-carbon buildings and renewable energy sources. The aspects of energy efficiency for the 2017-2024 period demonstrates the least amount of positive externalities within the energy sector. The sector is characteristically burdened with negative external effects, whereas in the next period of 2024-2030, there is a significant development potential. In case of the building sector, there are less opportunities for development in the first half of the period, but the 2024-2030 phase shows much better results. This can also be seen on the size of the sphere. As for the transport sector, the number of positive externalities is notable in the 2017-2024 interval, and this can only show sublime changes for the next period.

The aspects of $\mathrm{CO}_{2}$ emission introduce no real opportunity for decreasing $\mathrm{CO}_{2}$ emission in the transport sector. There is almost only negative externalities being amassed in the sector without any positive effects. The most important causes for such a phenomenon are probably the aging vehicle park, the increase in distance travelled, and the high amount of $\mathrm{CO}_{2}$ released by the sector. In case of the building sector, there is a strong positive development for this aspect which means decreasing $\mathrm{CO}_{2}$ emission rates.

Furthermore, the positive externality content is expected to increase in the 2024-2030 period, which shows the sector's GHG emission decrease potential. This relates to how low carbon emission buildings (smart buildings) and renewable energy sources are preferred, and to the political interventions related to these factors. In the case of the energy sector, there is a high amount of positive externalities for both periods. Although, in the 2030 period, the costs of $\mathrm{CO}_{2}$ decrease may be serious due to the CCS technological solutions. 
Also, due to the presence of nuclear energy, environmental risks also play a role, which makes the cost dimension of nuclear energy to have a significant effect. Fossilised energy resources will be notably apparent in the system until 2030. Therefore, a significant GHG emission decrease potential lacks in the sector.

\section{SUMMARY}

For all sectors, the integration of circular economy's principles into the planning processes is suggested. The novelty of the concept is in the fact that this genre mainly focuses on preventing the appearance of waste. The consideration of the circular economy principles may prove to be a strong pillar of sustainable development for various sectors. Until 2030, decision makers must aim at increasing efficiency for transport vehicles and decreasing their $\mathrm{CO}_{2}$ emission rates using novel technological solutions. Furthermore, even more importantly, models based on sharing economy - public solutions for transport - have to be designed and implemented. As for the energy sector, integrating renewable energy resources into the system can make emission rates decrease significantly even in mid-term. In case of buildings, already accessible low-carbon solutions, increasing the number of functions of the buildings and their longer usage may prove to be the sector's chance to decrease its GHG emission rates. Regarding both buildings and roads, secondary resources can be used quite efficiently, by which the sector's emission rates can be lowered. The results will mostly vary between mid- and long-terms, due to the life cycle of buildings. By integrating the circular system elements into planning processes, these sectors can be guided towards a development route which allows costefficiency, sustainable development, functionality, lower $\mathrm{CO}_{2}$ emissions, and social-economic aspects to be represented on a system-level.

\section{REFERENCES}

[1] PARKES O., LETTIER P., BOGLE IDL. Life cycle assessment of integrated waste management systems for alternative legacy scenarios of the London Olympic Park. Waste Management, Volume 40 (2015), pp. 157-166.http://dx.doi.org/10.1016/j.wasman.2015.03.017

[2] EPSTEIN D., JACKSON R, BRAITHWAIT, P.2011. Delivering London 2012: sustainability strategy. Proceedings of the Institution of Civil Engineers - Civil Engineering, Volume 164 (2011), No. 5, pp. 27-33.http://dx.doi.org/10.1680/cien.2011.164.5.27

[3] SONG T., WANG y. Carbon dioxide fluxes from an urban area in Beijing. Atmospheric Research, Volume 106 (2012), pp. 139149. http://dx.doi.org/10.1016/j.atmosres.2011.12.001

[4] LEOPKEY B., PARENT, мM. 2011. Olympic Games legacy: from general benefits to sustainable long-term legacy. The International Journal of the History of Sport. Volume 29 (2011), No. 6, pp. 924-943.http://dx.doi.org/10.1080/09523367.2011.623006

[5] SAMUEL s., stubBs w. Green Olympics, green legacies? An exploration of the environmental legacies of the Olympic Games. International Review for the Sociology of Sport, Volume 48 (2012), No. 4, pp. 485-504. http://dx.doi.org/10.1177/101269 0212444576

[6] воROCZ м, HORVATH в, HERCZEG в, KOVACS A. Greener cement sector and potential climate strategy development between 2015-2030 (Hungarian case study). APSTRACT - Applied Studies in Agribusiness and Commerce Volume 9 (2015), No. 4, pp. 65-74. http://dx.doi.org/10.19041/APSTRACT/2015/4/9

[7] CAMP RC. Learning from the best leads to superior performance. Journal of Business Strategy, Volume 13 (1992), No. 3, pp. 3-6. http://dx.doi.org/10.1108/eb039486

[8] FOGARASSY CS., HORVATH B. Climate policy cost-benefit model application for successful Central European building retrofitting programs - A Hungarian case study. International Journal of Engineering Business Management, Volume 9 (2017), No. (1), pp. 1-8. http://dx.doi.org/10.1177/1847979017717574 
[9] FORSTER D.,OKAMURA S., WILKINS G., MORRIS M., SCOTT P., KUIKMAN P., LESSCHENJ.P. GARDINER A.,BOERMANS T., GRÖZINGER J., EICHHAMmer w., REICHARDT K. Next phase of the European Climate Change Programme: Analysis of Member States actions to implement the Effort Sharing Decision and options for further community-wide measures. AEA group, Harwell, United Kingdom, 2012.

[10] KLinCKenberg F., PIRIE F M., MCANDrew L. Renovation Roadmaps for Buildings. Report by The Policy Partners for Eurima, London, England, 2013.

[11] arcipowska A., ANAgnostopoulos F., MARIottini F., KUnKel s. Energy Performance Certificates Across The EU - A Mapping of National Approaches. Buildings Performance Institute Europe (BPIE). Brussels, Belgium, 2014

[12] FOGARASSY CS., HORVATH в. Low-carbon building innovation trends and policy perspectives in Hungary between 2020 and 2030. YBL Journal of Built Environment, Volume 3 (2015), No. 2, pp. 17-23. http://dx.doi.org/10.1515/jbe-2015-0005

[13] MAVIR. A Magyar Villamosenergia-rendszer fogyasztói igényeinek előrejelzése [The forecast of the Hungarian electricity system consumer demands]. MAVIR, Budapest, Hungary, 2015.

[14] NFM. Nemzeti Energiastratégia 2030 [National Energy Strategy 2030]. Ministry of National Development, Budapest, Hungary, 2012.

[15] NFM. Magyarország Megújuló Energia Hasznosítási Cselekvési Terve 2010-2020 [Hungary’s Renewable Energy Action Plan 2010-2020]. Ministry of National Development, Budapest, Hungary, 2011.

[16] fogarassycs., kovacs A. The cost-benefit relations of the future environmental related development strategies in the Hungarian energy sector. YBL Journal of Built Environment, Volume 4 (2016), No. 1, pp. 33-48.http://dx.doi.org/10.1515/ jbe-2016-0004

[17] FOgARASSY CS., KOVACS A., HORVATH B., BOROCZ M. The development of a Circular Evaluation (CEV) tool - case study for the 2024 Budapest Olympics. Hungarian Agricultural Engineering, Volume 31 (2017), pp. 10-20. http://dx.doi.org/10.17676/ HAE.2017.31.10

[18] CAPRos P., DE VITA A.,TASIOS N., PAPADOPOUlOS D., SISKOS P., APOSTOLAKI E., ZAMPARA M., PAROUSSOS L., FRAGIADAKIS K., KOUVARITAKIS N., HÖGLUND-ISAKSSON L., WINIWARTER w., PUROHIT P., BÖTTCHER H., FRANK S., HAVLíK P., GUSTI M., WITZKE H. P. EU Energy, Transport and GHG Emissions, Trends to 2050, Reference Scenario 2013. European Commission, Brussels, Belgium, 2013.

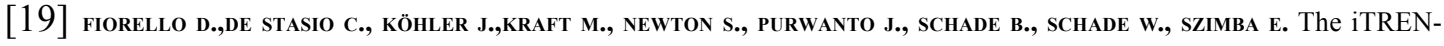
2030 reference scenario until 2030. Deliverable 4 of iTREN-2030 (Integrated transport and energy baseline until 2030). Fraunhofer ISI, Karlsruhe, Germany, 2009.

[20] hill N.,BRANNigan C., SMOKERS R., SCHROTEN A., ESSEN H., SKINNER I. Developing a better understanding of the secondary impacts and key sensitivities for the decarbonisation of the EU's transport sector by 2050. Final project report. AEA group, Harwell, United Kingdom, 2012.

[21] INTERNATIONAL OLYMPIC COMMitTEe. Sustainability through sport - implementing the Olympic movement's Agenda 21, 2012, pp. 38-48. 


\section{Appendices 1.}

Indicator system of the building sector (2017-2030)

\begin{tabular}{|c|c|c|c|}
\hline Code & State indicators & Code & $\begin{array}{c}\text { Performance indicators } \\
\text { (with method of formation) }\end{array}$ \\
\hline & \multicolumn{3}{|c|}{ Aspects of Renewable Energy share } \\
\hline 1 & $\begin{array}{l}\text { Specific analysis of the energy } \\
\text { mix used, its general attributes }\end{array}$ & 1 & $\begin{array}{l}\text { Change in usage of non-renewable energy } \\
\text { resources, increase or decrease of fossilised } \\
\text { energy resource usage for 2017-2030 }\end{array}$ \\
\hline 2 & $\begin{array}{l}\text { Overall quality and improvement } \\
\text { possibilities of technical } \\
\text { equipment, machinery }\end{array}$ & 2 & $\begin{array}{l}\text { State of technical quality, share of } \\
\text { environment-friendly technology }\end{array}$ \\
\hline 3 & $\begin{array}{l}\text { Attributes of taking part in waste } \\
\text { energetic recycling system }\end{array}$ & 3 & $\begin{array}{l}\text { Evaluation based on assisting } \\
\text { renewable energy systems }\end{array}$ \\
\hline 4 & $\begin{array}{l}\text { Level of environmental management, } \\
\text { general sector attributes of } \\
\text { environmental management systems }\end{array}$ & 4 & $\begin{array}{c}\text { Effects of EPC energy performance } \\
\text { authorisation on decrease } \\
\text { potential of buildings }\end{array}$ \\
\hline 5 & $\begin{array}{l}\text { Results and relations of benchmarking } \\
\text { emission and immission values }\end{array}$ & 5 & Share of emission level decrease potential \\
\hline 6 & $\begin{array}{l}\text { Complexity of resource efficiency, labour } \\
\text { market effects, effects on employment }\end{array}$ & 6 & $\begin{array}{l}\text { Job creation effect analysis, } \\
\text { evaluation of its importance }\end{array}$ \\
\hline
\end{tabular}

Table 1. First indicator group of the building sector's benchmarking analysis

\begin{tabular}{|c|c|c|c|c|}
\hline & Code & State indicators & Code & $\begin{array}{l}\text { Performance indicators } \\
\text { (with method of formation) }\end{array}$ \\
\hline & & \multicolumn{3}{|c|}{ Aspects of increasing Energy Efficiency } \\
\hline \multirow{2}{*}{ 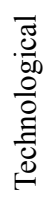 } & 1 & $\begin{array}{l}\text { Usage of electricity within } \\
\text { all energy usage }\end{array}$ & 1 & $\begin{array}{l}\text { What amount does the building sector } \\
\text { has from total electricity usage }\end{array}$ \\
\hline & 2 & $\begin{array}{l}\text { Level of opportunity for } \\
\text { using cleantech }\end{array}$ & 2 & $\begin{array}{l}\text { Usage of cleantech only for modernised } \\
\text { buildings (disregarding new buildings) }\end{array}$ \\
\hline \multirow{2}{*}{ 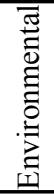 } & 3 & Intensity of input usage in the sector & 3 & Energy usage of the building sector \\
\hline & 4 & $\begin{array}{l}\text { Level of optimising } \\
\text { lifecycle of buildings }\end{array}$ & 4 & $\begin{array}{l}\text { Amount of zero energy and efficient } \\
\text { energy performance buildings }\end{array}$ \\
\hline \multirow{2}{*}{ 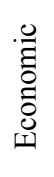 } & 5 & $\begin{array}{l}\text { Cost efficiency parameters of } \\
\text { increasing energy efficiency }\end{array}$ & 5 & Share of cost-efficient decrease potential \\
\hline & 6 & $\begin{array}{l}\text { Attributes of increasing } \\
\text { eco-efficiency }\end{array}$ & 6 & Amount of investments / savings \\
\hline
\end{tabular}

Table 2. Second indicator group of the building sector's benchmarking analysis 


\begin{tabular}{|c|c|c|c|c|}
\hline & Code & State indicators & Code & $\begin{array}{l}\text { Performance indicators } \\
\text { (with method of formation) }\end{array}$ \\
\hline & & \multicolumn{3}{|c|}{ Aspects of decreasing $\mathrm{CO}_{2}$ emission } \\
\hline \multirow{2}{*}{$\begin{array}{l}\overline{0} \\
.00 \\
00 \\
0 \\
0 \\
0 \\
0 \\
0\end{array}$} & 1 & $\begin{array}{l}\text { Intensity of GHG emission } \\
\text { according to technology }\end{array}$ & 1 & $\begin{array}{l}\text { GHG emission based on available } \\
\text { technological changes' evaluation }\end{array}$ \\
\hline & 2 & $\begin{array}{l}\text { Opportunities to introduce low- } \\
\text { carbon technology in the sector }\end{array}$ & 2 & $\begin{array}{l}\text { Level of applicability of known } \\
\text { low-carbon technologies }\end{array}$ \\
\hline \multirow{2}{*}{ 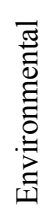 } & 3 & $\begin{array}{l}\text { Environmental attributes of } \\
\text { emitted greenhouse gases }\end{array}$ & 3 & $\begin{array}{l}\text { Characteristics of GHGs' environmental } \\
\text { effects, their evaluation from the } \\
\text { perspective of expected interventions }\end{array}$ \\
\hline & 4 & $\begin{array}{l}\text { Structure and volume index } \\
\text { of most notable GHGs }\end{array}$ & 4 & Changes in $\mathrm{CO}_{2}$ decrease ratios. \\
\hline \multirow{2}{*}{ 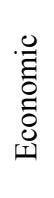 } & 5 & $\begin{array}{l}\text { Level of environmental } \\
\text { risks for emission }\end{array}$ & 5 & $\begin{array}{l}\text { Attributes and quality of } \\
\text { adaptation interventions }\end{array}$ \\
\hline & 6 & $\begin{array}{l}\text { Usual costs for GHG } \\
\text { avoidance by unit of } \mathrm{CO}_{2 \mathrm{e}}\end{array}$ & 6 & $\begin{array}{l}\text { Cost index of } \mathrm{CO}_{2 \mathrm{e}} \text { decrease } \\
\text { for the sector in question }\end{array}$ \\
\hline
\end{tabular}

Table 3. Third indicator group of the building sector's benchmarking analysis

Indicator system of the energy sector (2017-2030)

\begin{tabular}{|c|c|c|c|c|}
\hline & Code & State indicators & Code & $\begin{array}{l}\text { Performance indicators } \\
\text { (with method of formation) }\end{array}$ \\
\hline & & \multicolumn{3}{|c|}{ Aspects of Renewable Energy share } \\
\hline \multirow{2}{*}{$\begin{array}{l}\bar{\pi} \\
.00 \\
00 \\
0 \\
0 \\
0 \\
0 \\
0\end{array}$} & 1 & $\begin{array}{l}\text { Specific analysis and usual } \\
\text { attributes of applied energy mix }\end{array}$ & 1 & $\begin{array}{l}\text { Change in usage of non-renewable energy } \\
\text { resources, increase or decrease of fossilised } \\
\text { energy resource usage in the sector }\end{array}$ \\
\hline & 2 & $\begin{array}{c}\text { General quality and modernisation } \\
\text { possibilities of technical } \\
\text { machines and tools }\end{array}$ & 2 & $\begin{array}{l}\text { Possibilities of modernising technical } \\
\text { quality among given economic conditions }\end{array}$ \\
\hline \multirow{2}{*}{ 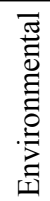 } & 3 & $\begin{array}{l}\text { Level and attributes of utilising } \\
\text { renewable energy resources }\end{array}$ & 3 & $\begin{array}{c}\text { Possibilities of using renewable energy } \\
\text { sources in the sector, possibilities } \\
\text { of increasing share in the sector }\end{array}$ \\
\hline & 4 & $\begin{array}{l}\text { Attributes of taking part in waste } \\
\text { energetic recycling system }\end{array}$ & 4 & $\begin{array}{l}\text { Evaluation based on assisting } \\
\text { renewable energy systems }\end{array}$ \\
\hline \multirow{2}{*}{ 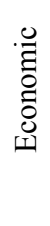 } & 5 & $\begin{array}{l}\text { Results and relations } \\
\text { of benchmarking emission } \\
\text { and immission values }\end{array}$ & 5 & $\begin{array}{l}\text { Possibility of decreasing emission } \\
\text { levels using renewable energy sources }\end{array}$ \\
\hline & 6 & $\begin{array}{l}\text { Complexity of resource } \\
\text { efficiency, labour market effects, } \\
\text { effects on employment }\end{array}$ & 6 & $\begin{array}{l}\text { Job creation effect analysis, } \\
\text { evaluation of its importance }\end{array}$ \\
\hline
\end{tabular}

Table 4. First indicator group of the energy sector's benchmarking analysis 


\begin{tabular}{|c|c|c|c|c|}
\hline & Code & State indicators & Code & $\begin{array}{l}\text { Performance indicators } \\
\text { (with method of formation) }\end{array}$ \\
\hline & & \multicolumn{3}{|c|}{ Aspects of increasing Energy Efficiency } \\
\hline \multirow{2}{*}{$\begin{array}{l}\bar{\Xi} \\
.00 \\
00 \\
0 \\
0 \\
0 \\
0 \\
\oplus\end{array}$} & 1 & $\begin{array}{l}\text { Share of nuclear energy usage } \\
\text { within total energy usage }\end{array}$ & 1 & $\begin{array}{l}\text { Evaluating the quality of nuclear } \\
\text { energy usage, basis is EU practice }\end{array}$ \\
\hline & 2 & $\begin{array}{l}\text { Level of opportunity for } \\
\text { using cleantech }\end{array}$ & 2 & $\begin{array}{l}\text { Opportunities of introducing low- } \\
\text { carbon technological solutions }\end{array}$ \\
\hline \multirow{2}{*}{ 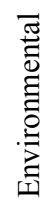 } & 3 & Opportunity to use industrial ecology & 3 & $\begin{array}{l}\text { Specifics of system attributes } \\
\text { aiding circular processes }\end{array}$ \\
\hline & 4 & Level of optimising lifecycle of waste & 4 & $\begin{array}{l}\text { Practice of using waste for } \\
\text { energetic purposes }\end{array}$ \\
\hline \multirow{2}{*}{$\begin{array}{l}.0 \\
\tilde{E} \\
0 \\
0 \\
0 \\
\text { In }\end{array}$} & 5 & $\begin{array}{l}\text { Cost-benefit parameters of } \\
\text { increasing energy efficiency }\end{array}$ & 5 & $\begin{array}{l}\text { Cost-benefit analysis based on } \\
\text { general technological levels }\end{array}$ \\
\hline & 6 & $\begin{array}{c}\text { Specific costs of } \\
\text { increasing eco-efficiency }\end{array}$ & 6 & $\begin{array}{l}\text { Eco-efficiency analyses based } \\
\text { on general sector attributes }\end{array}$ \\
\hline
\end{tabular}

Table 5. Second indicator group of the energy sector's benchmarking analysis

\begin{tabular}{|c|c|c|c|c|}
\hline & Code & State indicators & Code & $\begin{array}{l}\text { Performance indicators } \\
\text { (with method of formation) }\end{array}$ \\
\hline & & \multicolumn{3}{|c|}{ Aspects of decreasing $\mathrm{CO}_{2}$ emission } \\
\hline \multirow{2}{*}{$\begin{array}{l}\bar{\pi} \\
.00 \\
00 \\
0 \\
0 \\
0 \\
0 \\
\oplus\end{array}$} & 1 & $\begin{array}{l}\text { Intensity of GHG emission } \\
\text { according to technology }\end{array}$ & 1 & $\begin{array}{l}\text { GHG emission based on the evaluation of } \\
\text { available technological solution variants }\end{array}$ \\
\hline & 2 & $\begin{array}{l}\text { Opportunities to introduce low- } \\
\text { carbon technology in the sector }\end{array}$ & 2 & $\begin{array}{l}\text { Level of applicability of known } \\
\text { low-carbon technologies }\end{array}$ \\
\hline \multirow{2}{*}{ 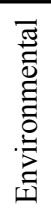 } & 3 & $\begin{array}{c}\text { Structure and volume index } \\
\text { of most notable GHGs }\end{array}$ & 3 & $\begin{array}{c}\text { Characteristics of generic GHG } \\
\text { emission for the area }\end{array}$ \\
\hline & 4 & $\begin{array}{l}\text { Environmental attributes } \\
\text { of emitted gases }\end{array}$ & 4 & $\begin{array}{l}\text { Characteristics of harmful emission's } \\
\text { environmental attributes, from the } \\
\text { perspective of expected interventions }\end{array}$ \\
\hline \multirow{2}{*}{$\begin{array}{l}.0 \\
\tilde{0} \\
0 \\
0 \\
0 \\
\text { I }\end{array}$} & 5 & $\begin{array}{l}\text { Level of environmental } \\
\text { risks for emission }\end{array}$ & 5 & $\begin{array}{l}\text { Attributes and quality of } \\
\text { adaptation interventions }\end{array}$ \\
\hline & 6 & $\begin{array}{l}\text { Usual costs for } \mathrm{GHG} \\
\text { avoidance by unit of } \mathrm{CO}_{2 \mathrm{e}}\end{array}$ & 6 & $\begin{array}{l}\text { Cost index of } \mathrm{CO}_{2 \mathrm{e}} \text { decrease } \\
\text { for the sector in question }\end{array}$ \\
\hline
\end{tabular}

Table 6. Third indicator group of the energy sector's benchmarking analysis 
Indicator system of the transport sector (2017-2030)

\begin{tabular}{|c|c|c|c|c|}
\hline \multirow{2}{*}{ Code } & \multicolumn{2}{|c|}{ State indicators } & Code & \multicolumn{2}{|c|}{$\begin{array}{c}\text { Performance indicators } \\
\text { (with method of formation) }\end{array}$} \\
\hline \multirow{2}{*}{ Aspects of Renewable Energy share } \\
\hline
\end{tabular}

Table 7. First indicator group of the transport sector's benchmarking analysis

\begin{tabular}{|c|c|c|c|c|}
\hline & Code & State indicators & Code & $\begin{array}{l}\text { Performance indicators } \\
\text { (with method of formation) }\end{array}$ \\
\hline & & \multicolumn{3}{|c|}{ Aspects of increasing Energy Efficiency } \\
\hline \multirow{2}{*}{ 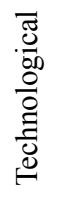 } & 1 & $\begin{array}{l}\text { Usage of electricity within } \\
\text { all energy usage }\end{array}$ & 1 & $\begin{array}{l}\text { Evaluating the quality of energy } \\
\text { usage, using comparison }\end{array}$ \\
\hline & 2 & $\begin{array}{l}\text { Level of opportunity for } \\
\text { using cleantech }\end{array}$ & 2 & $\begin{array}{l}\text { Opportunities of introducing low- } \\
\text { carbon technological solutions }\end{array}$ \\
\hline \multirow{2}{*}{ 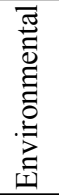 } & 3 & Intensity of input usage in the sector & 3 & Energy usage of the transport sector \\
\hline & 4 & $\begin{array}{l}\text { Level of optimising } \\
\text { lifecycle of vehicles }\end{array}$ & 4 & $\begin{array}{l}\text { Share of vehicles less than five } \\
\text { years old among all vehicles }\end{array}$ \\
\hline \multirow{2}{*}{ 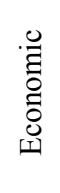 } & 5 & $\begin{array}{l}\text { Cost-benefit parameters of } \\
\text { increasing energy efficiency }\end{array}$ & 5 & Share of cost-efficient decrease potential \\
\hline & 6 & $\begin{array}{l}\text { Specific costs of increasing } \\
\text { eco-efficiency }\end{array}$ & 6 & $\begin{array}{l}\text { Changes in the ratio of urban } \\
\text { and rural public road traffic }\end{array}$ \\
\hline
\end{tabular}

Table 8 . Second indicator group of the transport sector's benchmarking analysis 


\begin{tabular}{|c|c|c|c|c|}
\hline & Code & State indicators & Code & $\begin{array}{l}\text { Performance indicators } \\
\text { (with method of formation) }\end{array}$ \\
\hline & & \multicolumn{3}{|c|}{ Aspects of decreasing $\mathrm{CO}_{2}$ emission } \\
\hline \multirow{2}{*}{$\begin{array}{l}\bar{J} \\
.00 \\
00 \\
0 \\
0 \\
0 \\
0 \\
-0\end{array}$} & 1 & $\begin{array}{l}\text { Intensity of GHG emission } \\
\text { according to technology }\end{array}$ & 1 & $\begin{array}{l}\text { GHG emission based on the evaluation of } \\
\text { available technological solution variants }\end{array}$ \\
\hline & 2 & $\begin{array}{l}\text { Opportunities to introduce low- } \\
\text { carbon technology in the sector }\end{array}$ & 2 & $\begin{array}{l}\text { Changes in the share of public } \\
\text { transport and public road traffic }\end{array}$ \\
\hline \multirow{2}{*}{ 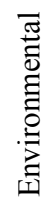 } & 3 & $\begin{array}{l}\text { Structure and volume index } \\
\text { of most notable GHGs }\end{array}$ & 3 & $\begin{array}{l}\text { Decrease potential of } \mathrm{CO}_{2} \text { share } \\
\text { in all GHG emission }\end{array}$ \\
\hline & 4 & $\begin{array}{l}\text { Environmental attributes } \\
\text { of emitted gases }\end{array}$ & 4 & $\begin{array}{l}\text { Characteristics of harmful emission's } \\
\text { environmental attributes, from the } \\
\text { perspective of expected interventions }\end{array}$ \\
\hline \multirow{2}{*}{ 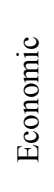 } & 5 & $\begin{array}{l}\text { Level of environmental } \\
\text { risks for emission }\end{array}$ & 5 & $\begin{array}{l}\text { Attributes and quality of } \\
\text { adaptation interventions }\end{array}$ \\
\hline & 6 & $\begin{array}{l}\text { Usual costs for GHG } \\
\text { avoidance by unit of } \mathrm{CO}_{2 \mathrm{e}}\end{array}$ & 6 & $\begin{array}{l}\text { Cost index of } \mathrm{CO}_{2 \mathrm{e}} \text { decrease } \\
\text { for the sector in question }\end{array}$ \\
\hline
\end{tabular}

Table 9. Third indicator group of the transport sector's benchmarking analysis 